\title{
What is gun culture? Cultural variations and trends across the United States
}

\author{
Claire Boine ${ }^{1 凶}$, Michael Siegel ${ }^{1}$, Craig Ross ${ }^{1}$, Eric W. Fleegler ${ }^{2} \&$ Ted Alcorn $^{3}$
}

We developed empirical methods to identify variations in elements of gun culture across states. Using these methods, we then analyzed the prominence of these subcultures between states and over time from 1998 through 2016. Using state-level data, we conducted a principal component analysis of 11 variables associated with gun-related behaviors and retained only the significant components. We then analyzed the presence of these components over time and across states. Based on the principal component analysis, we identified three cultural variations. Component 1 reflected recreational elements of gun culture. Component 2 represented a self-defense element of gun culture. Component 3 was indicative of a symbolic cultural element centered around the protection of the Second Amendment and insurrectionism. Over time, the recreational cultural element declined in prominence while the self-defense one rose and the Second Amendment advocacy one remained stable. This paper advances the literature on gun culture by demonstrating that: (1) gun culture is not monolithic; (2) there are multiple elements of gun culture that vary substantially between states; (3) over time, the recreational gun subculture has been falling in prominence whereas the self-defense subculture has been rising; and (4) there is another subculture, distinct from the self-defense one, which consists in mobilization around the Second Amendment and was strongest in places where state firearm laws are most extensive.

\footnotetext{
${ }^{1}$ Boston University School of Public Health, Boston, MA, USA. ${ }^{2}$ Harvard Medical School, Boston, MA, USA. ${ }^{3}$ Columbia University Mailman School of Public Health, New York, NY, USA. ${ }^{凶}$ email: cboine@bu.edu
} 


\section{Introduction}

W

hile there have been many studies in the public health literature about the illegal uses of guns (i.e. gun violence), few studies have examined the legal uses of guns and the cultural elements associated with gun ownership. As Yamane has argued, "without understanding this [the lawful ownership and use of guns], scholars cannot understand American gun culture" (Yamane, 2018, p. 158). However, in the sociology literature, the study of the lawful uses of firearms has only recently emerged (Yamane, 2018).

Hays has defined culture as "a social, durable, layered pattern of cognitive and normative systems that are once material and ideal, objective and subjective, embodied in artifacts and embedded in behavior, passed about in interaction, internalized in personalities and externalized in institutions" (Hays, 1994, p. 65). It follows that "gun culture" refers to the social, durable, and layered pattern of cognitive and normative systems embodied in firearms as both artifacts and vehicles of that culture. Gun culture encompasses how both individuals and institutions consciously and unconsciously interact with firearms, through beliefs, thoughts, behaviors, social and legal norms, as well as the social structures they project onto them. It includes the social interactions elicited or transformed by the existence of firearms, as well as the reciprocal influences between individuals, groups, and institutions in regards to firearm ownership and use.

The term "gun culture" was coined in 1970 by Hofstadter who viewed it as monolithic and described it as the Americans' unique belief in the "notion that the people's right to bear arms is the greatest protection of their individual rights and a firm safeguard of democracy" (Hofstadter, 1970). At the very time Hofstadter published his article, the National Rifle Association (NRA) had not yet become the political lobby we know today and still included many members open to firearm regulation (Dawson, 2019). Hofstadter's definition, limited to a single political view, failed to account for a range of various beliefs, behaviors, norms, and institutions. Many researchers who have followed have similarly defined gun culture in a narrow and monolithic way. In fact, the predominant line of research in this area uses a single variable-Southernness-as a measure of gun culture, assuming that it is only prevalent in the South (Brennan et al., 1993; Cohen and Nisbett, 1994; Puddifoot and Cooke, 2002; Felson and Pare, 2010; Altheimer and Boswell, 2012).

Of the few studies that do not rely on Southernness to characterize gun culture, most have still defined it monolithically. For example, in a survey, Kalesan et al. operationalized exposure to gun culture by asking respondents whether their family or friends would think less of them if they did not own a gun, and whether their social life with family or friends involved guns (Kalesan et al., 2015). Witkowski analyzed images spread by Second Amendment advocates to understand the ideology of the "core gun culture in the United States" (Witkowski, 2014). Lemieux characterized gun culture by measuring the revenues of all movies that glorified the use of guns (Lemieux, 2014). Goss used the percentage of a state's population that belongs to the NRA as a proxy for the gun culture of a state (Goss, 2006).

These approaches are greatly limiting. Assigning gun culture to the American South alone assumes that all states within that region share a single gun culture and that no states outside the South partake in it. It also ignores other historical, cultural, and structural factors characteristic of the South, subsuming them under the rubric of gun culture. Characterizing gun culture according to any single measure of gun-related behavior fails to account for observed variations in attitudes and behaviors related to firearms.

There have been attempts to disaggregate gun culture into multiple elements. Several studies have distinguished between self-protection and recreational groups (Bordua and Lizotte, 1979; Lizotte et al., 1981; Wright et al., 2017; Cook and Ludwig, 1996. Celinska, 2007; Legault and Lizotte, 2009; Yamane, 2017, 2018; Yamane et al., 2019). For example, Yamane distinguished between two elements of gun culture: (1) recreation or serious leisure (i.e., hunting, target shooting, and collecting) and (2) self-defense. Yamane noted that while the recreational, sporting, and collecting gun subculture (which Yamane denoted Gun Culture 1.0) is declining, the self-defense subculture (which he called Gun Culture 2.0) is on the rise (Yamane, 2017, 2018; Yamane et al., 2019). In fact, Gallup polls from 2000 to 2014 reveal an increase from $35 \%$ to $63 \%$ in the proportion of adults who believe that having a gun in the home makes it a safer place (Gallup, 2018).

These efforts to disaggregate gun culture have moved the field forward but have not developed an empirical method for systematically defining and measuring gun culture elements. This paper attempts to fill that gap by identifying variables available at the state-level which could potentially be associated with gun culture. The two strengths of this approach are: (1) it attempts to characterize elements of gun culture empirically based on a large number of gun-related variables; and (2) by analyzing data at the state level, it avoids the previous problems of treating regions as homogeneous.

We examine a range of potential variables that may be associated with gun culture, and use principal component analysis (PCA) to identify distinct combinations of those variables that describe different elements of gun culture.

\section{Materials and methods}

Design overview. We constructed a panel of annualized data on gun-related variables for all 50 states from 1998 to 2016. We then used a PCA to group these variables into different elements of American gun culture. Based on the magnitude of their eigenvalues, three components were retained.

Data sources and measures. Existing survey research shows that individual gun owners vary in the types of gun-related behaviors they practice and the beliefs they hold (Wertz et al., 2018). We also know that firearm-related social structures such as gun laws vary between states. Therefore, we hypothesize that there could exist measurable variations in gun culture across states.

In our attempt to identify and empirically measure elements of gun culture, we examined 11 variables: (1) the number of per capita hunting licenses; (2) the number of per capita NRA members; (3) the share of NRA members who subscribe to the magazine The American Hunter; (4) the share of NRA members who subscribe to the magazine America's 1st Freedom; (5) the share of NRA members who subscribe to the magazine American Rifleman; (6) the per capita number of subscriptions to the most popular gun-related magazine (Guns and Ammo); (7) per capita purchases of handguns; (8) per capita purchases of long guns; (9) the presence of a "stand your ground" law; (10) the presence of a ban on assault weapons, and (11) the per capita number of federally licensed gun dealers.

The first variable we used was the per capita number of hunting licenses per state. Hunting licenses have been used as an instrumental variable for firearm accessibility in previous studies (Kleck and Patterson, 1993). Hunting is in itself embedded in systems of meaning. Hays defines systems of meaning as "the beliefs and values of social groups, but also their language, forms of knowledge, and common sense, as well as the material products, interactional practices, rituals, and ways of life established by these" (Hays, 1994, p. 65). 
Different types of hunting hold different meanings associated with distinct symbols and practices. In Modern Age England, most lands that enabled hunting were privately owned and hunting was a way for members of the aristocracy to collectively affirm their social status (Howe and Fox, 1981; Herman, 2005; Proctor, 2009). Howe establishes that hunting has been a ritual. With a specific language that is impenetrable to non-hunters, and elements of sacralization and symbolism, hunters were replaying the social order in place (Howe and Fox, 1981). In the United States, indigenous populations partly relied on hunting for sustenance, and it was a male-dominated activity. During the colonial times, white settlers were encouraged to hunt because it gave them a paramilitary training. It mostly comprised of subsistence hunting, which enabled men to demonstrate their masculinity by directly providing for their households (Proctor, 2009). In the 19th century, new meanings were attributed to hunting. Because it had historically been reserved for aristocrats, it became a symbol of democracy in the newly formed United States. However, hunting was then mostly available to the wealthy elites and became a sport for white upper-class men. Theodore Roosevelt declared in 1893 that hunting promoted "vigorous manliness" (Grandy et al., 2003). Manhood became associated with the ability to kill with restraint and self-control (Proctor, 2009).

It is only after the first world war, when firearm manufacturers significantly increased production and decreased prices, that hunting spread to lower classes in spite of the elite's attempt to limit that process (Herman, 2005). These tensions between elitism and democracy in hunting have remained to this day, and different types of hunting hold different stances on the issue, such as exotic game hunting and canned hunting being perceived as elitist and unsporting (Herman, 2005). Lobbying groups have pushed for states to inscribe the right of the people to hunt into their constitutions and seven states have done so (Alabama, Florida, Minnesota, Missouri, New Hampshire, North Dakota, Virginia) (Grandy et al., 2003). Hunting is also still strongly associated with conservative gender norms. In spite of an increase in female hunters, $99 \%$ of hunters remain men, and hunting is used as a rite of passage from boyhood into manhood (Proctor, 2009). Finally, hunting also carries its own moral rules such as fairness, in the way the prey is killed, or wildlife conservation (Herman, 2005). In connection to the deep social structure of hunting, firearms are altogether a tool, a symbol and an artifact. They enable laymen to access an activity that has historically been viewed as an aristocratic privilege. They facilitate the transition from boyhood into manhood. They provide places of primary and secondary socialization through hunts with family members, and within more distant circles.

The annual number of paid hunting licenses was obtained from the U.S. Fish and Wildlife Service. We included only paid hunting licenses, not permits or tags for crossbow hunting or for the ability to hunt specific animals. Thus, we are measuring licenses for firearm-related hunting only.

The second variable we included was the per capita number of members of the NRA in each state. The NRA was originally founded in 1871 by two Union army officers who were surprised at the lack of shooting skills of average soldiers during the Civil War. The goal of the organization was to provide firearm training to promote marksmanship. To this day, the NRA is the main provider of firearm trainings. However, from the beginning, one of the reasons for the NRA's success was that some, who were concerned with the feminization of men in relation to social Darwinism in the 19th century, viewed the organization as a way to encourage masculinity as well as instill in the youth the American values of independence, self-reliance, moral strength, and reverence to God. This aspect of the NRA was further reinforced during the Cold War (Mechling, 2014). The association, comparable to other organizations such as Boy Scouts of America, has played a major role in socialization of many of its members from a young age. In the 1920s and 1930s, NRA leaders lobbied in favor of landmark gun control legislation (Winkler, 2011).

The NRA turned into an advocacy organization in the 1970s as a backlash to liberalism from the 1960s (Waldman, 2014). In 1975, it created the Institute for Legislative Action, its lobbying arm. During the NRA convention of 1977 in Cincinnati, a revolt started that led to the exclusion of the executive vice president Maxwell Rich, which opened the way for a new leadership centered on the Second Amendment. The NRA started focusing on the Second Amendment, using its historic core values of masculinity, self-reliance and reverence to God (Melzer, 2009; Waldman, 2014; Dawson, 2019). In 1981, they hired a communication firm, Ackerman McQueen, to help them with their messaging (Coffee, 2019). After two major gun control laws were passed at the national level in 1993, the NRA expanded its rhetoric about government overreach until Executive Vice President Wayne LaPierre created a scandal in 1995 by referring to federal agents as "jack-booted Government thugs" (Horwitz et al., 2009, p. 37). In addition, the NRA alienated members of the law enforcement community by opposing legislation designed to prevent civilians from buying armor-piercing handgun ammunition. These events led to the departure of many NRA members, including President George W. Bush himself (Horwitz et al., 2009).

As a result, the NRA changed strategy and tried to disassociate itself and "regular" gun owners from white power and militia movements (Dawson, 2019; Melzer, 2009). In 1998, which is the start of our study period, they elected Charlton Heston as the president of the organization (Janofky, 1998). They also embraced a broader conservative agenda to form closer ties with Republican leaders (Horwitz et al., 2009). This is when the organization created a new publication focused mostly on politics and the Second Amendment, the American Guardian, later renamed America's First Freedom.

Today, the NRA is still mostly focused on the defense of the Second Amendment. Although some gun owners may join the NRA to gain access to specific exclusive shooting competitions or discounted hunting material, membership in the NRA may reflect the general level of gun-related activism in a state (Horwitz et al., 2009). Goss has argued that "there is a reliable way to measure anticontrol sentiment: by measuring the fraction of the state's population that belongs to the National Rifle Association ... NRA membership is a reasonable proxy of "gun culture", or anticontrol sentiment, in a given state" (Goss, 2006, pp. 220-221). It has been estimated that $\sim 6 \%$ of gun owners belong to that organization (Ingraham, 2015). However, it has been well documented that NRA members are extremely active politically and civically (Melzer, 2009; Lacombe, 2019). In addition to being a social group and a social movement, the NRA is also a system of meaning with its own values, rituals (e.g. Pledge of Allegiance at NRA conventions), artifacts (NRA carry card, magazines, famous figures, music), and in-group and out-group language (Melzer, 2009; Lacombe, 2019). Furthermore, as well as promoting the Second Amendment, it relays conservative values and upholds specific systems of social relations such as traditional gender relations (Horwitz et al., 2009; Melzer, 2009).

Upon joining the NRA, each new member is offered a free subscription to a magazine distributed exclusively by the NRA. Until July 2016, a new member could choose between three different magazines: The American Hunter, The American Rifleman, and America's 1st Freedom. Goss proposed that by adding the number of paid subscriptions to these three magazines 
in each state, one can generate an estimate of the number of NRA members in a state (Goss, 2006). The Alliance for Audited Media (AAM) measures the volume of paid subscriptions to each of these magazines and reports the data at the state level (Alliance for Audited Media, Media Intelligence Center, 2018). We purchased from AAM state-specific subscription data for these three NRA magazines for the years 1998-2016, which we used to approximate the number of NRA members in each state.

We also included in our analysis the share of NRA members who subscribe to the following periodicals:

- The American Rifleman is the NRA's longest-running magazine. It was created in 1885 under the name The Rifle. Published monthly since it was renamed in 1923, it features historical and technical articles about firearms, editorials by the president of the NRA, and the column "The Armed Citizen", which "highlight accounts of law-abiding gun owners in America using their Second Amendment rights to defend self, home, and family" (National Rifle Association, 2020).

- The American Hunter was introduced in 1973 and focuses almost exclusively on hunting.

- America's 1st Freedom, first published in 1997 as The American Guardian, was created by Ackerman McQueen just as the NRA was trying to rebrand itself and attract new members. It describes itself as "the magazine for NRA members dedicated to preserving our fundamental right to self-defense. Its primary objective is to provide breaking news on the latest anti-gun schemes and in-depth investigations into explosive topics that impact our gun rights" (National Rifle Association, 2018).

These three NRA magazines have several articles in common every month, including the editorial. However, because NRA members have to choose one publication upon joining the organization, the one they choose likely reflects their predominant interests, practices, and attitudes. Thus, the proportion of NRA members in a state that choose different magazines may provide some indication of the mix of gun-related interests among gun owners in that state. People primarily interested in hunting may be more likely to choose The American Hunter, and people with a strong interest in the defense of the Second Amendment may be more likely to choose America's 1st Freedom. The American Rifleman is of broader interest; the topic of selfdefense has been increasingly present in the publication since the 1970s (Yamane et al., 2019).

We also included the per capita number of subscriptions to the most popular gun-related magazine: Guns and Ammo, which is published by the Outdoor Sportsman Group. The number of subscribers, by state, has previously been used as an indicator of gun culture (Kleck, 2004). The Guns and Ammo media kit indicates that the publication is mostly geared toward general firearms enthusiasts and hunters. In $2018,79 \%$ of their readers reported having hunted in the past 12 months, and 57\% indicated they belonged to a gun club or organization (Outdoor Sportsman Group, 2018). Sociologists have longed viewed magazines as cultural artifacts, and have analyzed their content to reveal cultural elements of societies. In that sense, Guns and Ammo is an artifact of gun culture. Several authors analyzed its content. Jacobs and Villaronga studied it along with 76 other magazines, and classified Guns and Ammo in the "general interest" category as it is not as specialized as magazines targeting niche audiences, such as hunters or members of law enforcement (2004). Other analyses of the magazine demonstrated the relation between gun culture and broader cultural values. For instance, Hirschman showed that the periodical is a vehicle for the American core value of rugged individualism, and that it depicts individual freedom as God granted and inalienable (2003). Collins examined responses by the readers following a column written by Dick Metcalf who suggested that some limitations to the Second Amendment could be legitimate (2014). The journalist was then fired by the editorial board who issued an apology for the article. Collins' study is helpful in indicating that some of the readers of Guns and Ammo tied the fact that they owned firearms to their sense of identity. She quotes a reader who wondered: "was Metcalf faking it in past articles? Did others at Guns and Ammo know who he really was?" (p. 749). These questions show the perceived impermeable dichotomy between an in-group of gun owners and the out-group. By being disloyal, Metcalf switched sides.

In addition to both reflecting and shaping gun culture, Guns and Ammo might offer its readers an opportunity to express or reaffirm their identity as gun owners by appealing to collective values beyond possessing a firearm. We obtained the subscription data for Guns and Ammo from the AAM.

Our analysis also included the per capita purchases of handguns and long guns. While no database enumerates the number of annual firearm sales by state, state and federal agencies conduct background checks prior to gun sales by licensed gun dealers (and also before state agencies issue concealed carry permits), and this can serve as a proxy for legal firearm sales. On a monthly basis, for each state, the FBI reports the number of background checks conducted for handgun sales and for long gun sales. Gun sales do not necessarily reflect the general level of household gun ownership, and gun ownership and gun sales can vary independently. For example, from 1999 to 2016, the prevalence of household gun ownership in the U.S. dropped from $41 \%$ to $36 \%$. During the same time period, the average per capita number of background checks for all guns increased from 3.5 to 5.3. The per capita number of background checks is thus an especially sensitive variable as it can experience sharp acute changes based on collective perceptions of specific events. For instance, within one month of the election of President Obama in 2008, which was perceived as a threat by many gun owners, 1.1 million guns were sold (Aisch and Keller, 2016). It is therefore a direct measure of interaction between gun owners and society. Historically, long gun purchases were motivated by an interest in hunting whereas handgun purchases were motivated by an interest in self-defense (Steidley, 2019), so these two variables are likely associated with distinct cultural elements.

We included the number of federally licensed gun dealers per capita as a measure of the general demand for guns in a state. Wintemute showed that about $60 \%$ of legal purchases of guns take place through federally licensed gun dealers (2002), which were determined to be a good indicator of urban firearm ownership and used as a variable in previous studies (Wiebe et al., 2009). The annual number of federally licensed gun dealers in each state does not vary as much and is a structural variable. It was obtained from the Bureau of Alcohol, Tobacco, Firearms, and Explosives (2020).

Given the mutual influence between institutions and agents, laws are an important part of culture. To represent the state's firearm-related political or regulatory culture, we ascertained the presence or absence of two types of firearm laws: stand-yourground laws and assault weapon bans. We used the State Firearm Laws Database for this purpose (2018). Stand-your-ground laws, which remove the duty to retreat in public spaces, enable armed individuals to shoot someone first if they perceive a threat of severe injury or death. Several authors demonstrated that standyour-ground laws were associated with self-defense (Carlson, 2015a, 2015b; Stroud, 2016). Carlson also indicated that they are connected to gun culture more broadly: "Stand Your Ground laws, aimed at expanding America's ability to use guns for self- 
defense, show that the NRA is not just a lobbying organization but also a proactive shaper of gun culture" (Carlson, 2015a, p. 6). Light established that the concept behind stand-your-ground laws is historically rooted in the castle doctrine in 17th century England (2017). She determined that this new ideology arose at a time of contestation of the monarchy and extended to white male owners who wanted to protect their property. At the time, it was upheld by a landmark case in which police officers were found at fault as they burst into someone's home without announcing themselves (Light, 2017). Stand-your-ground laws are also rooted in the history of the U.S. in which "delegating law and order to local communities surrounded by enemies implied a proactive and frequent use of violence on the part of regular citizens" (Obert, 2018 , p. 217). Therefore, in collective consciousness, these laws can in turn have connections to other ideologies such as private property, insurrectionism, or patriotism. Stand-your-ground laws also epitomize the strongest ideological divide between Second Amendment activists and gun violence prevention advocates: whether individual carry makes society safer or more dangerous. These laws invoke the idea that citizens are responsible for their own protection and thus convey a specific conception of the state not having the monopoly over legal violence.

Assault weapon bans were included in this analysis because there are one of the only firearm laws that literally consist of taking firearms away from their owners, and are, as a result, one of the least popular firearm policies among gun owners. A 2018 Quinnipiac University Poll reported that assault weapon bans are the gun control policy least favored by gun owners and support for such a policy is drastically lower than support for universal background checks. While $97 \%$ of respondents in gun households supported universal background checks and 77\% supported waiting periods for all gun purchases, only 53\% supported bans on assault weapons (Quinnipiac University, 2018). Thus, the presence or absence of an assault weapons ban in a state may be a reflection of the extent to which gun owners in that state perceive threats to legal gun ownership.

It is well established that nationwide, many of these variables shifted substantially during the study period. For instance, there was a massive increase in handgun sales (Smith et al., 2017) and a shift in gun purchasers' reported motivations for gun ownership from hunting to self-defense (Azrael et al., 2017). In this paper, we aimed to characterize these changes at the state level, which might suggest differences in the mix of gun cultural elements between states.

We analyzed data beginning in the year 1998 because the American Guardian, later renamed America's 1st Freedom, was first published late in 1997.

\section{Analysis}

PCA is commonly used to create the minimal number of necessary components to explain the greatest amount of variance among a group of variables. Two advantages of this methodology are: (1) it groups variables together organically; and (2) once defined, the components can be used as variables that represent the different elements of gun culture in subsequent statistical analysis.

We first standardized the 11 gun culture variables with a mean of 0 and a variance of 1 , and then conducted a PCA of these standardized variables. We retained only the components with an eigenvalue above 1 (Kaiser, 1960). We then explored the differences in each component between states and their changes between 1998 and 2016, both within states and across the United States. The analysis was conducted using Stata (version 15) and reproduced in python, using the NumPy package. Figure 2 was produced with Tableau's free academic license.

After generating the components, we measured their correlation with a range of socio-demographic variables. We obtained data on the state land area, the percentages of the population that were Black, Hispanic, non-White, and living in an urban area, the unemployment rates, and the population density from the U.S. Census Bureau (2018). We measured changes in the number of state firearm laws using data from the State Firearm Laws Database (2018). We obtained state conservatism scores from Shor and McCarthy (2011). We obtained the per capita number of police officers from the FBI's Uniform Crime Reports (2018).

\section{Results}

Overview of the components. We report the content and eigenvalue of each component in Table 1 . Component 1 consisted primarily of hunting license rates, Guns and Ammo readership, American Hunter readership, NRA membership, per capita long gun checks, and the density of federally licensed gun dealers. Component 2 consisted of per capita handgun checks, the presence of a stand your ground law, and American Rifleman readership. Component 3 was made up of the percentage of NRA members who subscribed to the American Guardian and later America's 1st Freedom, per capita NRA membership, and the presence of an assault weapon ban.

Based on the component loadings, we theorize that:

(1) Component 1 reflects the level of recreational gun-related behaviors in a state, such as hunting and leisure;

(2) Component 2 reflects self-protection and self-defense; and

(3) Component 3 reflects Second Amendment activism.

\section{Table 1 Principal component analysis.}

\begin{tabular}{|c|c|c|c|}
\hline Variable & Component 1 & Component 2 & Component 3 \\
\hline Per capita number of federally licensed gun dealers & 0.39 & 0.03 & 0.29 \\
\hline Per capita number of licensed hunters & 0.40 & 0.06 & -0.03 \\
\hline Per capita Guns and Ammo magazine subscribers & 0.38 & -0.04 & 0.27 \\
\hline Per capita readers of American Hunter & 0.34 & -0.34 & -0.31 \\
\hline Per capita number of long gun background checks & 0.32 & 0.32 & -0.08 \\
\hline Per capita NRA membership & 0.37 & 0.18 & 0.37 \\
\hline Per capita number of handgun background checks & 0.10 & 0.59 & 0.05 \\
\hline Presence of a state stand-your-ground law & 0.03 & 0.47 & -0.47 \\
\hline Per capita readers of American Rifleman & -0.30 & 0.32 & 0.25 \\
\hline Per capita readers of America's 1st Freedom & -0.24 & 0.21 & 0.27 \\
\hline Presence of a state assault weapon ban & -0.19 & -0.18 & 0.49 \\
\hline Eigen value & 5.35 & 2.12 & 1.02 \\
\hline
\end{tabular}




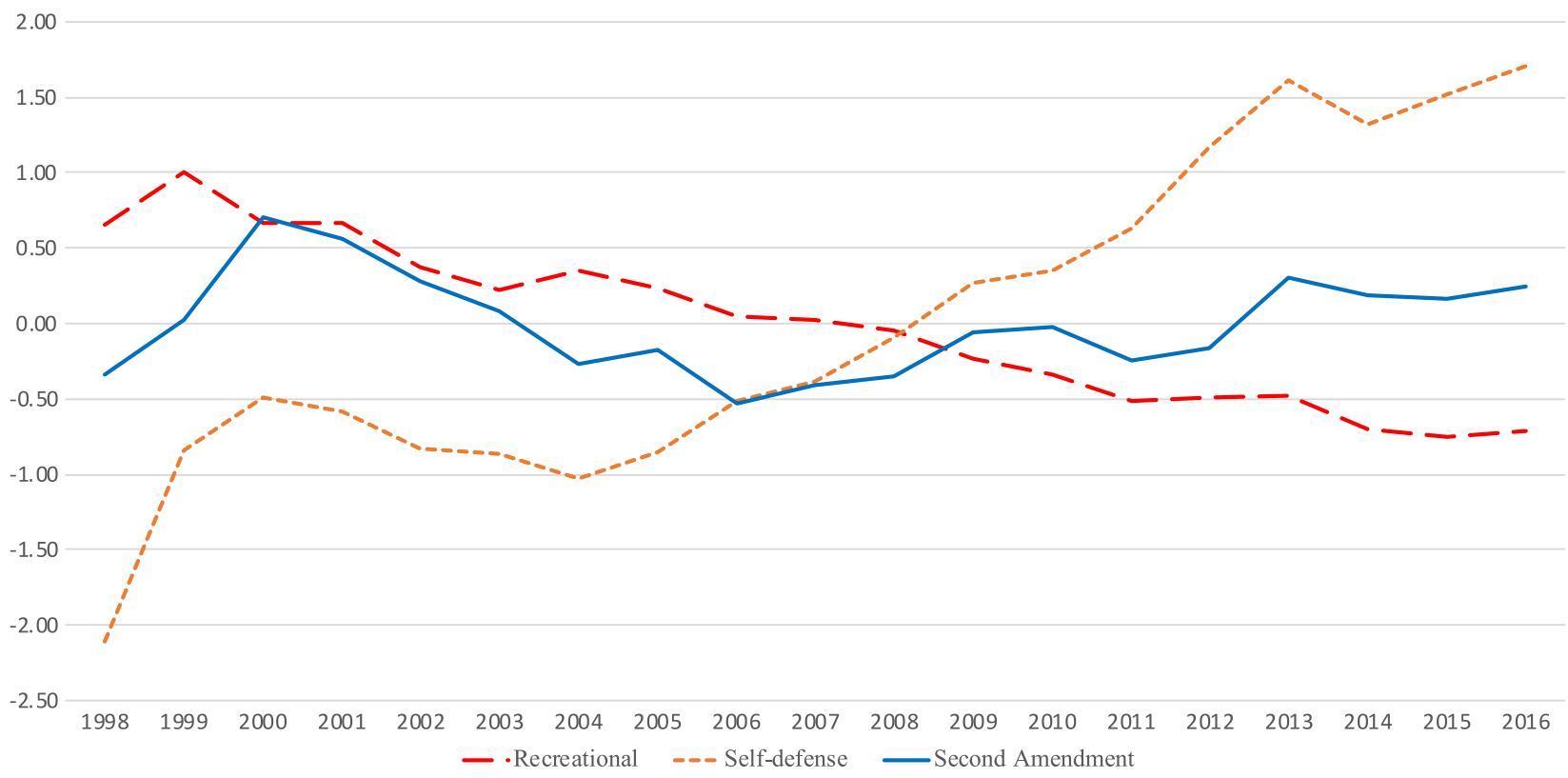

Fig. 1 Changes in cultural elements across the U.S. over time (1998-2016).

Component 1 is composed of variables that reflect recreational use of firearms. It is comprised of hunting-related variables such as the number of licensed hunters (with a component loading of 0.40 ), the share of NRA members who choose The American Hunter (0.34), and the number of background checks for long gun sales (0.32). It is also comprised of the per capita readership of Guns and Ammo (0.38), a generic firearm periodical geared toward hunting and other recreational activities such as target shooting. Component 1 also included the per capita number of federally licensed gun dealers (0.39) and NRA membership (0.37), both of which indicate the general level of gun activity in a state.

Component 2 is composed of variables that reflect an interest in self-defense. The number of background checks for handgun sales (with a loading of 0.59 ) is mostly associated with individual carry for self-defense purposes (McDowall, 1995), while the presence of a stand-your-ground law (0.47) reflects the state's interest in the value of guns as a tool for self-defense (Carlson, 2015a, 2015b; Stroud, 2016). This component also includes the readership of American Rifleman (0.32), which has given an increasing role to self-defense in its advertising content (Yamane et al., 2019).

Component 3 was comprised of two variables related to Second Amendment activism: per capita NRA membership (0.37), and the proportion of NRA members who chose America's 1st Freedom (0.27). It also contained the presence of an assault rifle ban (0.49), which is a policy perceived by gun owners as a threat to gun ownership. Although the NRA was originally created in 1871 to promote marksmanship, the organization is now primarily dedicated to expanding gun ownership through policy (Melzer, 2009) and the state per capita NRA membership can be seen as a measure of Second Amendment activism in that state.

America's 1st Freedom is a magazine that portrays the Second Amendment as being under threat, and it argues that the right to bear arms is the most fundamental freedom which secures all the other individual rights. The name of the magazine comes from a speech delivered by Charlton Heston, in which the actor stated that the Second Amendment is "America's first freedom, the one that protects all the others" (Seelye, 1997). The proportion of NRA members who subscribe to the magazine thus reflects the extent to which local NRA members' primary concern is the protection of the Second Amendment.
The presence of assault weapon bans in Component 3 seems to indicate that the states with the least popular firearm regulations in place also have the most Second Amendment activism. Second Amendment activism could therefore be a reaction to stronger state gun laws. The higher per capita NRA membership in these areas could either be a reaction to firearm legislation or could be fueling Second Amendment activism, or both.

The component scores presented in this study represent how much each data point varies from the mean over time (1998-2016) and across the U.S. For instance, in 2010, Louisiana had a score of 0 for the recreational cultural element. As a result, in 2010, the level of recreational-related firearm behaviors in the state of Louisiana was the same as the average of all recreationalrelated firearm behaviors across the country over the period 1998-2016.

Figure 1 depicts the evolution of each component over time nationally. Table 2 shows the change in each state. Nationally, Component 1 , the recreational cultural element, fell in prominence, from an average of +0.7 in 1998 to -0.7 in 2016. Over that period, states that experienced the largest declines were Alaska $(-3.7)$, Nevada $(-2.1)$, and Utah $(-2.1)$. Component 2, selfdefense, rose in prominence from an average of -2.1 in 1998 to 1.7 in 2016. Over that period, states that experienced the most growth were West Virginia $(+6.2)$, New Hampshire $(+6.2)$, South Dakota $(+6)$, and Tennessee $(+5.9)$. Component 3 , the Second Amendment activism subculture, which ranged between -0.5 and +0.7 , was most prominent, on average, in Alaska (2.3), Wyoming (2.1), Connecticut (2), California (1.9), and Massachusetts (1.5). It was least prominent in South Dakota $(-2.9)$, Louisiana (-1.5), Mississippi (-1.5), Wisconsin (-1.2), and Utah $(-1.1)$.

Figure 2 maps the distribution of the cultural elements across the United States and the mix of cultural elements specific to each state. Between 1998 and 2016, Component 1, the recreational cultural element, which ranged between +6 and -3.5 , was most prominent, on average, in Wyoming (6), Montana (5.7), Alaska (5.2), South Dakota (4.1) and North Dakota (3.8). It was least prominent in California $(-3.5)$, Hawaii $(-3.3)$, Massachusetts $(-3.2)$, New Jersey $(-3)$, and Rhode Island (-2.9). Between 1998 and 2016, Component 2, self-defense, which ranged between -2 and +1.5 , was most prominent, on average, in Alaska $(+1.5)$, 
Table 2 Change in each component per state between 1998 and 2016.

\begin{tabular}{|c|c|c|c|}
\hline State & $\begin{array}{l}\text { Change in } \\
\text { Component } 1\end{array}$ & $\begin{array}{l}\text { Change in } \\
\text { Component } 2\end{array}$ & $\begin{array}{l}\text { Change in } \\
\text { Component } 3\end{array}$ \\
\hline Alabama & -0.85 & +4.68 & +0.13 \\
\hline Alaska & -3.69 & +5.27 & -3.42 \\
\hline Arizona & -1.36 & +3.77 & -0.27 \\
\hline Arkansas & -1.47 & +3.59 & +1.38 \\
\hline California & -1.05 & +1.95 & +0.68 \\
\hline Colorado & -1.03 & +4.23 & +1.14 \\
\hline Connecticut & -1.10 & +3.27 & +1.16 \\
\hline Delaware & -1.16 & +3.60 & +1.70 \\
\hline Florida & -0.84 & +4.33 & +0.23 \\
\hline Georgia & -1.50 & +4.03 & +0.26 \\
\hline Hawaii & -1.22 & +0.66 & +0.21 \\
\hline Idaho & -1.67 & +3.32 & +0.48 \\
\hline Illinois & -1.03 & +3.18 & +1.45 \\
\hline Indiana & -0.97 & +5.14 & -0.08 \\
\hline lowa & -1.73 & +1.96 & +1.47 \\
\hline Kansas & -0.94 & +4.41 & 0.00 \\
\hline Kentucky & -1.15 & +4.60 & +0.07 \\
\hline Louisiana & -1.06 & +5.32 & +0.39 \\
\hline Maine & -1.09 & +4.14 & +1.21 \\
\hline Maryland & -2.02 & +1.33 & +2.57 \\
\hline Massachusetts & -2.00 & +1.33 & +2.67 \\
\hline Michigan & -1.83 & +3.72 & +0.06 \\
\hline Minnesota & -1.58 & +3.41 & +1.03 \\
\hline Mississippi & -1.63 & +5.50 & +0.18 \\
\hline Missouri & -1.04 & +5.79 & +0.34 \\
\hline Montana & -1.74 & +5.01 & -1.24 \\
\hline Nebraska & -1.61 & +1.79 & +1.09 \\
\hline Nevada & -2.12 & +3.91 & -0.21 \\
\hline New Hampshire & -1.06 & +6.17 & +0.39 \\
\hline New Jersey & -1.63 & +2.05 & +1.42 \\
\hline New Mexico & -1.07 & +3.43 & +0.87 \\
\hline New York & -1.70 & +0.94 & +2.47 \\
\hline North Carolina & -1.76 & +3.24 & +0.17 \\
\hline North Dakota & -1.09 & +3.97 & +0.78 \\
\hline Ohio & -1.02 & +3.78 & +1.63 \\
\hline Oklahoma & -0.39 & +5.35 & +0.15 \\
\hline Oregon & -1.59 & +4.12 & +0.29 \\
\hline Pennsylvania & -1.22 & +5.27 & +0.20 \\
\hline Rhode Island & -0.98 & +2.10 & +1.11 \\
\hline South Carolina & -1.37 & +4.57 & +0.56 \\
\hline South Dakota & -0.37 & +5.98 & -0.29 \\
\hline Tennessee & -0.87 & +5.87 & +0.28 \\
\hline Texas & -1.15 & +3.83 & -0.07 \\
\hline Utah & -2.07 & +2.69 & +0.98 \\
\hline Vermont & -1.76 & +3.23 & +0.26 \\
\hline Virginia & -1.01 & +3.80 & +1.33 \\
\hline Washington & -1.43 & +3.17 & +0.67 \\
\hline West Virginia & -1.05 & +6.23 & +0.23 \\
\hline Wisconsin & -1.42 & +3.78 & +1.14 \\
\hline Wyoming & -1.65 & +4.00 & +0.10 \\
\hline
\end{tabular}

Tennessee $(+1.4)$, Florida $(+1.3)$, Oklahoma $(+1.2)$, and Montana $(+1.2)$. It was least prominent in New York $(-2)$, New Jersey (-1.7), Nebraska (-1.7), Iowa ( -1.6$)$, and Wisconsin $(-1.4)$. After a brief increase from 1998 to 2000, and a slower decline from 2000 to 2006, the average prominence of the Second Amendment subculture nationwide increased slightly over the duration of the study period: from -0.3 in 1998 to +0.3 in 2016 (Fig. 1). Between 1998 and 2016, states that experienced the most growth in Component 3 were Massachusetts $(+2.7)$, Maryland $(+2.6)$, New York $(+2.5)$, Delaware $(+1.7)$, and Ohio $(+1.7)$. The only states that experienced a significant decline in Component 3 were Alaska (-3.4) and Montana (-1.2).
The most striking finding is that there are wide variations in the presence of the recreational gun culture between states (Fig. 2). Another interesting observation is that several states that are very low in recreational and self-defense cultural elements are high in Second Amendment advocacy, such as California, Connecticut, Massachusetts, and New Jersey.

Figures 3-5 display the mix of cultural elements in each state. States that have both high recreational and high Second Amendment advocacy subcultures are Alaska and Wyoming. States with low recreation and high Second Amendment advocacy are Massachusetts, California, and Connecticut. These states also experience low levels of the self-defense element. South Dakota has a high recreational element but a low Second Amendment advocacy element. Alabama has a high self-defense element, but low Second Amendment advocacy. Florida has one of the strongest self-defense elements, but is very low in terms of recreational gun use.

Table 3 depicts the correlation between the components and socio-demographic variables at the state level. The recreational element is associated with politically conservative states with large rural areas, little racial diversity and few firearm regulations. The self-defense element is correlated with politically conservative states with large rural areas that did not enact many firearm laws and are experiencing higher unemployment levels. The Second Amendment element is correlated with liberal states where a higher share of the population lives in an urban setting or is Hispanic, and with stronger firearm regulations.

\section{Discussion}

To our knowledge, this is the first study to use a large number of variables to empirically identify elements of gun culture at the state level and quantify the differences in the mix of these cultural variations across states and over time. We find that gun culture is not monolithic: we identified three distinct cultural elements that differed across and within states over time. This finding is consistent with Haag's thesis that "the discussion today is typically categorical (we either were or were not a gun culture), rather than dimensional (there are degrees, and different kinds of gun attachment). It is valuable to parse the matter and to ask questions-which guns, how were they made, why were they made, how are they used, by whom, and why do these users love themrather than to simply compress all gun milieus into one American gun culture. At the least, the gun "culture" might need to be pluralized into "cultures" (Haag, 2016, pp. 258-259).

The three components that we identified can be considered to be "cultural" according to the definition used in our analysis. For example, Kohn found that recreational or sporting subcultures, such as hunting, target shooting, or competition shooting "signify certain kinds of values, traditions, and/or ways of life that those gun owners see as part of their cultural heritage" (Kohn, 2006, p. 15). Both Stroud (2016) and Carlson (2015a) showed that ownership of guns for self-defense is not merely pragmatic, but is associated with an entire set of symbolic meanings that encompass personal identity, masculinity, power, freedom, racial attitudes, responsibility, morality, and views of governmental threat. The right to bear arms has been portrayed, largely by the NRA, not merely as a Constitutional right, but as the right from which all other rights and freedoms flow (Keene and Mason, 2016). As expressed by Keene and Mason (2016), "the real fight [about the Second Amendment] is not about this restriction or that law, but about the nature of American culture".

The presence of a distinct cultural element centered around Second Amendment activism is consistent with previous literature which showed that there exists a movement that does not view the defense of the Second Amendment as a means to an end, 


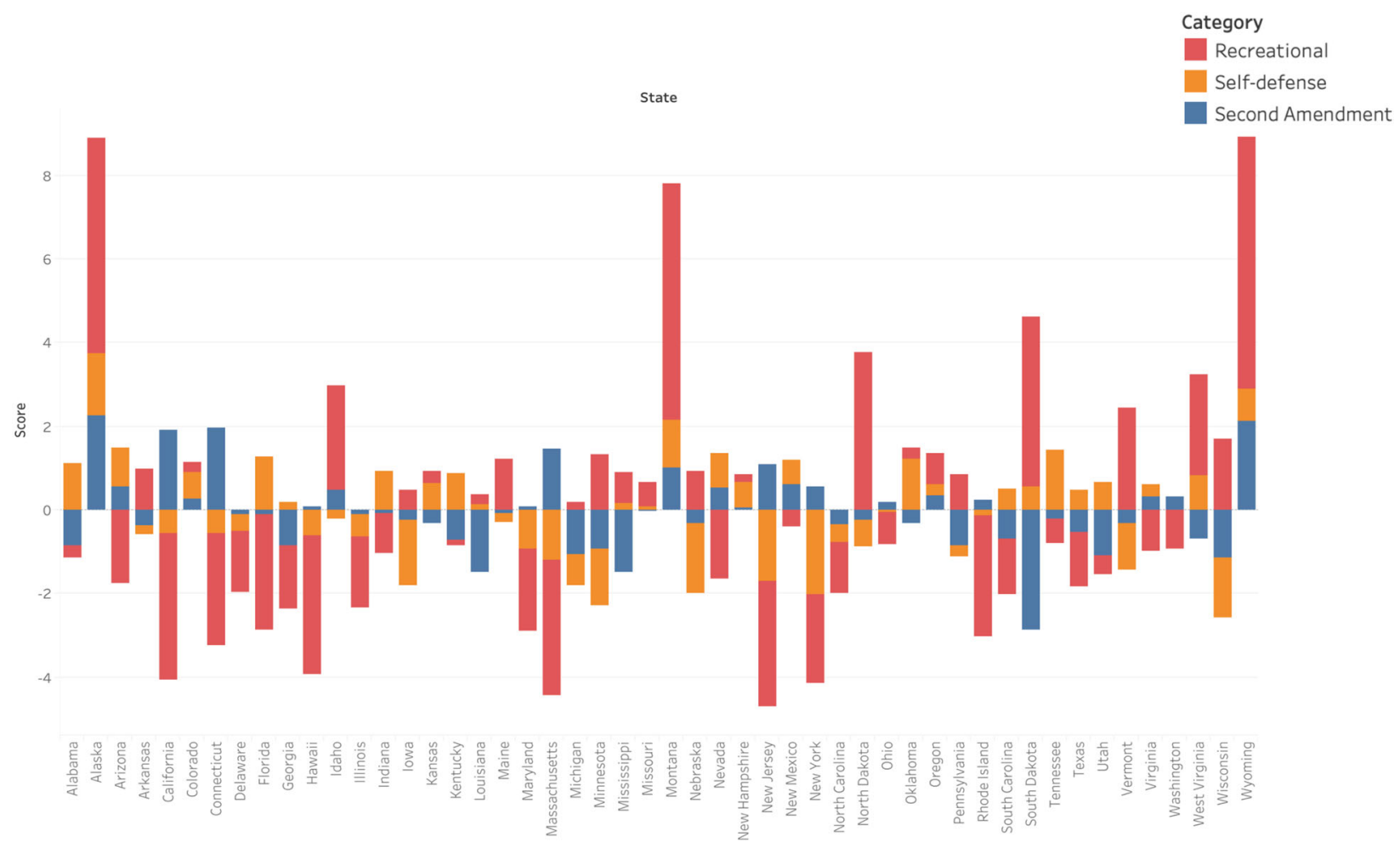

Fig. 2 Average cultural variations within and across states (1998-2016).

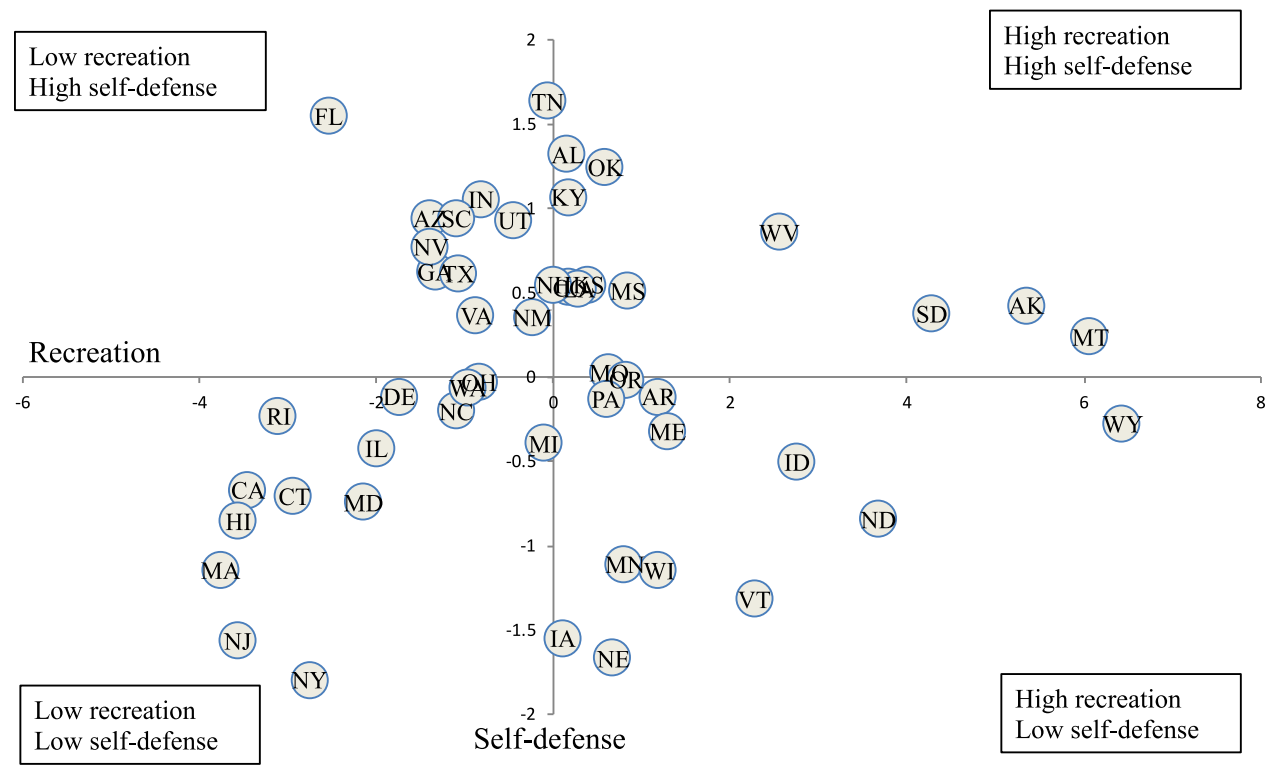

Fig. 3 Mix of state subcultures: Recreation/Self-Defense. Standardized component scores (representing the difference for a particular state from the mean for all states expressed in number of standard deviations) are shown for Recreation on the $x$-axis and for Self-Defense on the $y$-axis.

but that believes in the importance of gun ownership per se. As 12-year-old Texan boy Ashton puts it: "I like guns because they don't just represent hunting, target practice or competition. They represent freedom in the form of self-defense or in the case of the Second Amendment it means protection from the government" (Badessi, 2019). This theory that the Second Amendment is necessary to all other freedoms was explored by Anderson and Horwitz who showed that the NRA has embraced insurrectionist ideology (2009). Our finding that Massachusetts and Connecticut are low in the recreational element and high in the Second
Amendment one seems to substantiate their claim. About New England, they write: "the link between these original citizensoldiers and their guns has been carefully preserved at a host of Revolutionary War battlefields, monuments, and museum exhibits" (Anderson and Horwitz et al., 2009, p. 83). There, patriotism and the possibility of taking arms against an oppressive government are closely intertwined. As a result, it is not surprising that the NRA's insurrectionist argument and Second Amendment advocacy can be so popular in these states, in spite of their sparse recreational use of firearms. 


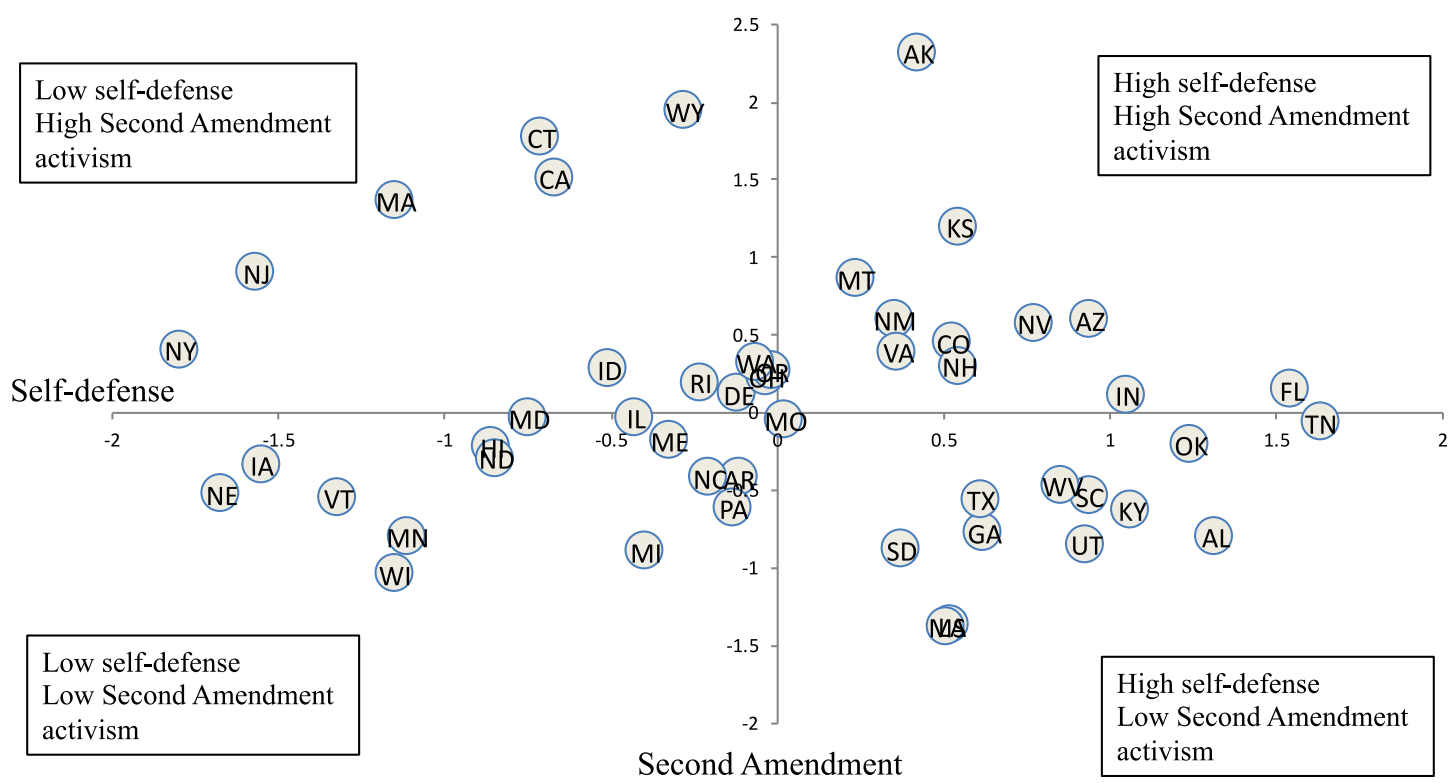

Fig. 4 Mix of state subcultures: Self-Defense/Second Amendment. Self-Defense/Second Amendment. Standardized component scores (representing the difference for a particular state from the mean for all states expressed in number of standard deviations) are shown for Self-Defense on the $x$-axis and for Second Amendment activism on the $y$-axis.

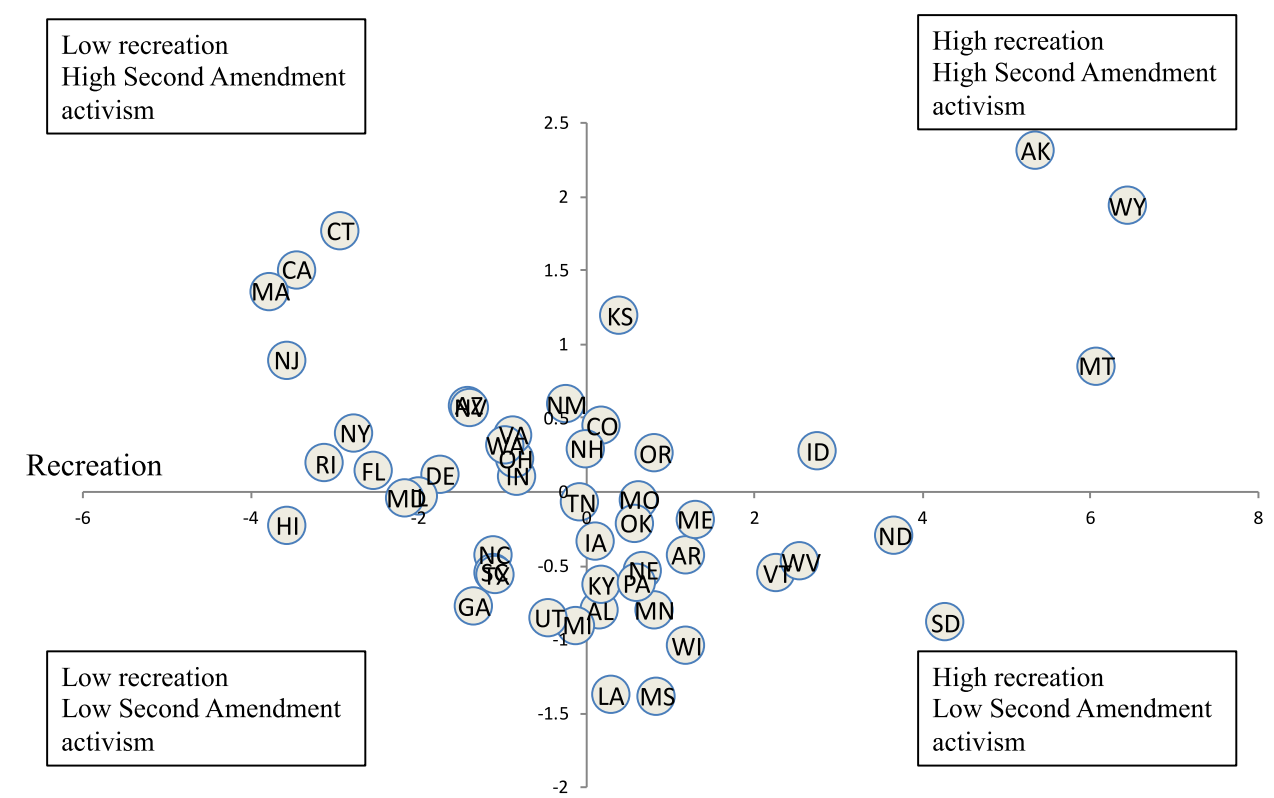

Second Amendment

Fig. 5 Mix of state subcultures: Recreation/Second Amendment. Standardized component scores (representing the difference for a particular state from the mean for all states expressed in number of standard deviations) are shown for Recreation on the $x$-axis and for Second Amendment activism on the $y$-axis.

Scholars have hypothesized about why Second Amendment advocates seem emotionally involved in the protection of gun ownership. Mencken and Froese established that American gun owners vary widely in the symbolic meaning they find in firearms; some associate gun ownership with moral and emotional empowerment and others do not (Mencken and Froese, 2019). Lacombe demonstrated that gun owners are very politically active because there is a collective social identity tied to gun ownership and therefore they feel personally invested (2019). Dawson determined that, as the NRA has been increasingly using religious language to refer to gun ownership, to some gun owners, the
Second Amendment became a right bestowed on them by God himself (Dawson, 2019).

The presence of this distinct cultural element is also consistent with a shift in firearm marketing and sales. Firearm advertising "moved from narrative-a description of how guns worked-to lyric-a description of how they made you feel" (Haag, 2016, p. 332). Melzer has described how former NRA president Charlton Heston strongly emphasized the idea of the gun as a symbol in the organization's discourse: "Heston emphasized that a gun is more than a physical object, it is a symbol; that is, its importance lies in its representation of a particular American ideology" 


\begin{tabular}{|c|c|c|c|}
\hline & Component 1 & Component 2 & Component 3 \\
\hline Conservatism score & 0.57 & 0.57 & -0.60 \\
\hline Unemployment & -0.25 & 0.30 & 0.01 \\
\hline Percent non-White & -0.62 & -0.17 & 0.15 \\
\hline Percent Black & -0.40 & 0.02 & -0.18 \\
\hline Percent Hispanic & -0.44 & -0.19 & 0.42 \\
\hline Percent urban & -0.71 & -0.31 & 0.40 \\
\hline Density & -0.62 & -0.40 & 0.54 \\
\hline Land area & 0.33 & 0.26 & -0.07 \\
\hline Per cap police officers & -0.34 & -0.29 & 0.35 \\
\hline $\begin{array}{l}\text { Number of state } \\
\text { firearm laws }\end{array}$ & -0.63 & -0.59 & 0.64 \\
\hline $\begin{array}{l}\text { Change in state } \\
\text { firearm laws }\end{array}$ & -0.49 & -0.53 & 0.63 \\
\hline
\end{tabular}

Absolute values above 0.3 were bolded for emphasis.

(Melzer, 2009, p. 121). As Metzl puts it, “addressing guns symbolically means recognizing ways that firearms emerge as powerful symbols shaped by history, politics, geography, economy, media, and culture, as well as by actors such as gun manufacturers or lobbying groups" (Metzl, 2019, p. 2).

Trend across the U.S. and over time. The decline we observe in the recreational element nationwide and within states and the increase we observe in the self-defense element are consistent with what Yamane has characterized as a shift from a Gun Culture 1.0 of leisure to a Gun Culture 2.0 oriented toward selfdefense (Yamane, 2017, 2018; Yamane et al., 2019).

We suspect that the observed variability in Component 3 in the first two years after its introduction was due to the novelty of The American Guardian. The prominence of Component 3 changed markedly within states. Except for Ohio, the states that experienced the greatest increase in Component 3 were also among those that enacted the largest number of new law provisions regulating firearms during the study period. By 2016, the number of firearm laws in Massachusetts, Maryland, New York, Ohio, and Delaware were, respectively, 101, 64, 76, 16, and 39 , compared with a national average of 26 firearm law provisions per state in 2016 (State Firearm Law Database, 2018). Outside of Ohio, which went from 21 firearm laws in 1998 to 18 in 2016, these states all experienced increases in their total number of firearm regulations. In addition, all five of these states experienced marked declines in Component 1, the recreational gun culture element.

In order to test this hypothesis that the Second Amendment cultural element might be related to the change in state firearm regulation, we measured the correlation between each component and the state absolute change in the number of firearm law provisions between 1998 and 2016 (Table 3). We found a strong negative correlation between the change in firearm state laws and the change in the recreational element $(-0.49)$ and in the selfdefense element $(-0.53)$, and a positive association between the change in firearm state laws and the Second Amendment element (0.63).

Implications. This paper has three implications for future research on gun culture and the symbolic meaning of legal gun use. First, it illustrates-for the first time-empirical methods that can be used to discern elements of gun culture from national data and to compare the differences in the mix of these elements across states and over time.
Second, the paper demonstrates how the identification of variations in cultural elements across states could potentially have value for exploring the symbolic meanings of guns and how these meanings may differ geographically.

Finally, this paper identifies a third cultural element that is distinct from both recreation and self-defense. This cultural element appears to represent a symbolic attachment to firearms as fundamental to individual freedom. This has been a major theme of the rhetoric of the NRA for more than 20 years. As Melzer states in a recent book chapter: "for more than two decades, the NRA has mobilized its activist base of members (and arguably many gun owners who are not members) by framing dire threats not only to the Second Amendment, but also to all individual rights and freedoms" (Melzer, 2019, p. 117). We found a strong correlation between increases in the Second Amendment cultural element within states and the number of gun laws enacted between 1998 and 2016. This suggests that this cultural element is a reaction to perceived threats to gun ownership, viewed more broadly as threats to individual freedoms.

\section{Conclusion}

This paper advances the literature on gun culture by demonstrating that: (1) gun culture is not monolithic; (2) there are multiple elements of gun culture that vary substantially between states; (3) over time, the recreational gun cultural variation has been falling in prominence whereas the self-defense element has been rising; and (4) there is another cultural element, distinct from the self-defense subculture, which consists in mobilization around the Second Amendment and was strongest in places where state firearm laws are most extensive. Because the attributes of these elements of gun culture are all highly correlated, the uncorrelated components we have identified can be used in future analysis as proxy variables for distinct cultural elements of legal gun ownership associated with them. Future research should explore the cultural elements and potential symbolic meanings of firearms identified in this paper using qualitative methods, such as conducting a national survey of gun owners.

\section{Data availability}

The dataset generated during the current study is not publicly available as it contains proprietary information that the authors acquired through a license. Information on how to obtain it and reproduce the analysis is available from the corresponding author on request.

Received: 28 June 2019; Accepted: 18 June 2020;

Published online: 08 July 2020

\section{References}

Aisch G, Keller J (2016) What happens after calls for new gun restrictions? Sales go up. The New York Times. https://www.nytimes.com/interactive/2015/12/10/ us/gun-sales-terrorism-obama-restrictions.html. Accessed 17 Mar 2020

Alliance for Audited Media, Media Intelligence Center (2018) https:// auditedmedia.com/data/media-intelligence-center. Accessed 31 Dec 2018

Quinnipiac University (2018) U.S. support for gun control tops 2-1, highest ever, Quinnipiac University National Poll Finds. Quinnipiac University, Hamden

Altheimer I, Boswell M (2012) Reassessing the association between gun availability and homicide at the cross-national level. Am J Crim Justice 37(4):682-704

Azrael D, Hepburn L, Hemenway D, Miller M (2017) The stock and flow of U.S. firearms: results from the 2015 National Firearms Survey. RSF 3(5):38-57

Badessi LE (2019) Age of innocence: children \& guns in the U.S.A. Introduction by Jennifer Carlson. Images Plurielles, Paris

Bordua DJ, Lizotte AJ (1979) Patterns of legal firearms ownership: a cultural and situational analysis of Illinois counties. Law Policy 1(2):147-175

Brennan PG, Lizotte AJ, McDowall D (1993) Guns, southernness, and gun control. J Quant Criminol 9(3):289-307 
Bureau of Alcohol, Tobacco, Firearms, and Explosives (2020) Federal firearms listing. https://www.atf.gov/firearms/listing-federal-firearms-licensees. Accessed 10 Apr 2020

Carlson J (2015b) Mourning Mayberry: guns, masculinity, and socioeconomic decline. Gend Soc 29(3):386-409

Carlson J (2015a) Citizen-Protectors: the everyday politics of guns in an age of decline. Oxford University Press, New York

Celinska K (2007) Individualism and collectivism in America: The case of gun ownership and attitudes toward gun control. Sociol Perspect 50(2):229-247

Coffee P (2019) Ackerman McQueen moves to terminate 38-year contract with the NRA. Adweek

Cohen D, Nisbett RE (1994) Self-protection and the culture of honor: explaining Southern violence. Pers Soc Psychol Bull 20(5):551-567

Collins LJ (2014) The second amendment as demanding subject: figuring the marginalized subject in demands for an unbridled second amendment. Rhetor Public Affairs 17:737-756

Cook P, Ludwig J (1996) Guns in America: results of a comprehensive national survey on firearm ownership and use. Police Foundation, Washington.

Dawson J (2019) Shall not be infringed: how the NRA used religious language to transform the meaning of the Second Amendment. Palgrave Commun 5 (1):1-13

Federal Bureau of Investigation (2018) Uniform crime reporting statistics. U.S. Department of Justice, Washington. http://www.ucrdatatool.gov. Accessed 7 July 2019

Felson RB, Pare PP (2010) Gun cultures or honor cultures? Explaining regional and race differences in weapon carrying. Soc Forces 88(3):1357-1378

Gallup (2018) Guns. https://news.gallup.com/poll/1645/guns.aspx. Accessed 7 July 2019

Goss KA (2006) Disarmed: the missing movement for gun control in America. Princeton University Press, Princeton

Grandy JW, Stallman E, Macdonald DW (2003) The science and sociology of hunting: shifting practices and perceptions in the United States and Great Britain. In: Salem D (ed) The state of the animals II. Humane Society Press, Washington, pp. 107-130

Haag P (2016) The gunning of America: business and the making of American gun culture. Basic Books, New York

Hays S (1994) Structure and agency and the sticky problem of culture. Sociol Theory 12(1):57-72

Herman DJ (2005) Hunting democracy. Montana 55:22-33

Hirschman EC (2003) Men, dogs, guns, and cars: the semiotics of rugged individualism. J Advert 32:9-22

Hofstadter R (1970) America as a gun culture. Am Heritage 21(6 October). https:// www.americanheritage.com/content/america-gun-culture. Accessed 30 Jan 2020

Horwitz J, Anderson C, Guns (2009) Democracy, and the insurrectionist idea. University of Michigan Press, Ann Arbor

Howe J, Fox (1981) Hunting as ritual. Am Ethnol 8:278-300

Ingraham C (2015) Most gun owners don't belong to the NRA-and they don't agree with it either. The Washington Post. https:/www.washingtonpost.com/ news/wonk/wp/2015/10/15/most-gun-owners-dont-belong-to-the-nra-andthey-dont-agree-with-it-either/. Accessed 30 Jan 2020

Jacobs JB, Villaronga D (2004) Mapping the U.S. gun culture: a content analysis of Gun Magazines. J. Firearms Pub Policy 16:135

Janofky M (1998) Enthusiastic N.R.A. gives mandate to Charlton Heston. The New York Times

Kaiser HF (1960) The application of electronic computers to factor analysis. Educ Psychol Meas 20:141-151

Kalesan B, Villarreal MD, Keyes KM, Galea S (2015) Gun ownership and social gun culture. Inj Prev 22(3):216-220

Keene DA, Mason TL (2016) Shall not be infringed: the new assaults on your Second Amendment. Skyhorse Publishing, New York

Kleck G (2004) Measures of gun ownership levels for macro-level crime and violence research. J Res Crime Delinq 41(1):3-36

Kleck G, Patterson E (1993) The impact of gun control and gun ownership levels on violence rates. J Quant Criminol 9(3):249-287

Lacombe MJ (2019) The political weaponization of gun owners: the National Rifle Association's cultivation, dissemination, and use of a group social identity. J Polit 81(4):1342-1356

Legault RL, Lizotte AJ (2009) Caught in a crossfire: legal and illegal gun ownership in America. In: Krohn MD, Lizotte AJ, Hall GP (eds) Handbook on crime and deviance. Springer, New York, pp. 456-491

Lemieux F (2014) Effect of gun culture and firearm laws on gun violence and mass shootings in the United States: a multi-level quantitative analysis. International. J Crim Justice Sci 9(1):74-93

Light C (2017) Stand your ground: a history of America's love affair with lethal self-defense. Beacon Press, Boston

Lizotte AJ, Bordua DJ, White CS (1981) Firearms ownership for sport and protection: two not so divergent models. Am Sociol Rev 46(4):499-503
McDowall D (1995) Firearms and self-defense. Ann Am Acad Pol Soc Sci 539 (1):130-140

Mechling J (2014) Boy scouts, the National Rifle Association, and the Domestication of Rifle Shooting. Am Stud 1(53):5-26

Melzer S (2009) Gun crusaders: the NRA's culture war. New York University Press, New York

Melzer S (2019) Fighting the left and leading the right: NRA politics and power through the 2016 elections. In: Carlson J, Goss KA, Shapira H (eds) Gun studies: interdisciplinary approaches to politics, policy and practice. Routledge, New York, pp. 117-135

Mencken FC, Froese P (2019) Gun culture in action. Soc Probl 66:3-27

Metzl JM (2019) What guns mean: the symbolic lives of firearms. Palgrave Commun 5:35. https://doi.org/10.1057/s41599-019-0240-y

National Rifle Association (2018) NRA publications 2018 guide to advertising http://www.nrapublications.org/media/1535172/rate_cards_magazines.pdf. Accessed 30 Jul 2019

National Rifle Association (2020) Armed citizen stories. https:/www.nraila.org/ gun-laws/armed-citizen/. Accessed 10 Apr 2020

Obert J (2018) The six-shooter state. Public and private violence in American politics. Cambridge University Press, Cambridge

Outdoor Sportsman Group (2018) Guns and Ammo 2018 media kit. http://www. outdoorsg.com/wp-content/uploads/2014/10/GA_2018_mediaKit-final.pdf. Accessed 31 Jul 2019

Proctor N (2009) Hunting. In: Bercaw N, Ownby T (eds) The New Encyclopedia of Southern Culture: Volume 13: Gender. University of North Carolina Press Chapel Hill, North Carolina, pp. 139-143

Puddifoot JE, Cooke CA (2002) Representations of handguns by young adults in the U.S. and UK. J Community Appl Soc Psychol 12(4):256-270

Seelye KQ (1997) Heston asserts gun ownership is nation's highest right. New York Times. https://www.nytimes.com/1997/09/12/us/heston-asserts-gun-ownershipis-nation-s-highest-right.html. Accessed 31 July 2019

Shor B, McCarty N (2011) The ideological mapping of American legislatures. Am Polit Sci Rev 105(3):530-551

Smith VM, Siegel M, Xuan Z, Ross CS, Galea S, Kalesan B, Fleegler EW, Goss KA (2017) Broadening the perspective on gun violence: An examination of the firearms industry, 1990-2015. Am J Prev Med 53(5):584-591

State Firearm Law Database (2018) http://www.statefirearmlaws.org. Accessed 30 Dec 2020

Steidley T (2019) The effect of concealed carry weapons laws on firearm sales. Soc Sci Res 78:1-11

Stroud A (2016) Good guys with guns: the appeal and consequences of concealed carry. The University of North Carolina Press, Chapel Hill

United States Census Bureau (2018) https://www.census.gov/topics/population. html. Accessed 30 Jul 2019

Waldman M (2014) The Second Amendment. Simon \& Schuster, New York

Wertz J, Azrael D, Hemenway D, Sorenson S, Miller M (2018) Differences between new and long-standing US gun owners: results from a national survey. Am J Public Health 108(7):871-877

Wiebe DJ, Krafty RT, Koper CS, Nance ML, Elliott MR, Branas CC (2009) Homicide and geographic access to gun dealers in the United States. BMC Public Health 9:199

Winkler A (2011) Gunfight: the battle over the right to bear arms in America. W. W. Norton \& Company, New York

Wintemute G (2002) Where the guns come from: the gun industry and gun commerce. Future Children 12(2):55-71

Witkowski TH (2014) The visual politics of U.S. gun culture. In: Belk RW, Price L Penaloza L (eds) Consumer culture theory, vol. 15. Emerald Group Publishing Limited, Bingley, pp. 3-23

Wright JD, Rossi PH, Daly K (2017) Under the gun: weapons, crime, and violence in America. Routledge, New York

Yamane D (2017) The sociology of U.S. gun culture. Sociol Compass 11:e12497. https://doi.org/10.1111/soc4.12497

Yamane D (2018) What's next? Understanding and misunderstanding America's gun culture. In: Hovey C, Fisher L (eds) Understanding America's gun culture. Lexington Books, Lanham, pp. 157-167

Yamane D, Ivory SL, Yamane P (2019) The rise of self-defense in gun advertising: the American Rifleman, 1918-2017. In: Carlson J, Goss KA, Shapira H (eds) Gun studies: interdisciplinary approaches to politics, policy and practice. Routledge, New York, pp. 29-51

\section{Acknowledgements}

We thank Jeffrey Krupa for his time discussing and proofreading the manuscript, as well as his general support. We thank mathematician David Rolnick, computer scientist Samantha Dale Strasser and physicist Andrew Turner for the multiple conceptual conversations about principal component analysis. This research was supported by a grant from the Robert Wood Johnson Foundation, Evidence for Action: Making Health a 
Shared Value program (grant \#76132). We thank all the people working on the Making Health a Shared Value framework for making this research possible.

\section{Competing interests}

The authors declare no competing interests.

\section{Additional information}

Correspondence and requests for materials should be addressed to C.B.

Reprints and permission information is available at http://www.nature.com/reprints

Publisher's note Springer Nature remains neutral with regard to jurisdictional claims in published maps and institutional affiliations. (c) (i) Open Access This article is licensed under a Creative Commons Attribution 4.0 International License, which permits use, sharing, adaptation, distribution and reproduction in any medium or format, as long as you give appropriate credit to the original author(s) and the source, provide a link to the Creative Commons license, and indicate if changes were made. The images or other third party material in this article are included in the article's Creative Commons license, unless indicated otherwise in a credit line to the material. If material is not included in the article's Creative Commons license and your intended use is not permitted by statutory regulation or exceeds the permitted use, you will need to obtain permission directly from the copyright holder. To view a copy of this license, visit http://creativecommons.org/ licenses/by/4.0/.

(C) The Author(s) 2020 